\title{
PEROGIES AND POLITICS
}

Canada's Ukrainian Left, 1891-1991 


\section{STUDIES IN GENDER AND HISTORY}

General Editors: Franca Iacovetta and Karen Dubinsky 
RHONDA L. HINTHER

\section{Perogies and Politics}

Canada's Ukrainian Left, 1891-1991

UNIVERSITY OF TORONTO PRESS

Toronto Buffalo London 
(C) University of Toronto Press 2018

Toronto Buffalo London

www.utppublishing.com

Printed in Canada

ISBN 978-1-4875-0049-8

( Printed on acid-free, $100 \%$ post-consumer recycled paper with

vegetable-based inks.

\section{Library and Archives Canada Cataloguing in Publication}

Hinther, Rhonda L., 1974-, author

Perogies and politics : Canada's Ukrainian left, 1891-1991 / Rhonda L. Hinther.

(Studies in gender and history)

Includes bibliographical references and index.

ISBN 978-1-4875-0049-8 (cloth)

1. Right and left (Political science) - Canada - History - 19th century.

2. Right and left (Political science) - Canada - History - 20th century.

3. Ukrainians - Canada - Politics and government -19 th century.

4. Ukrainians - Canada - Politics and government - 20th century.

I. Title. II. Series: Studies in gender and history

FC106.U5H56 2018 971.004'91791 C2017-903097-3

This book has been generously supported by the publications program of the Shevchenko Scientific Society of Canada and the Brandon University Research Committee.

University of Toronto Press acknowledges the financial assistance to its publishing program of the Canada Council for the Arts and the Ontario Arts Council, an agency of the Government of Ontario.

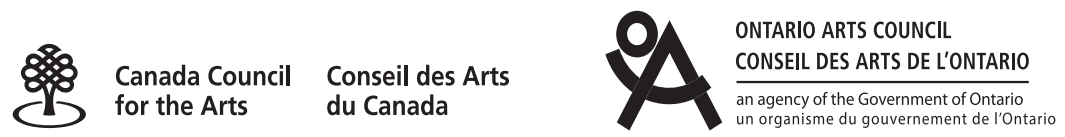

